\title{
Knowledge Sharing as Social Exchange: Evidence from a Meta-Analysis
}

\author{
Chih-Chung Liu \\ Chia Nan University of Pharmacy and Science \\ Tainan, Taiwan \\ birdy.liu@gmail.com
}

\author{
Ting-Peng Liang \\ National Chengchi University \\ Taipei, Taiwan \\ tp.liang@nccu.edu.tw \\ Vallabh. Sambamurthy \\ Michigan State University \\ Michigan, USA \\ sambamurthy@bus.msu.edu
}

\author{
Balaji Rajagopalan \\ Oakland University \\ Michigan, USA \\ rajagopa@oakland.edu \\ Jason Chia-Hsien Wu \\ National Sun Yat-Sen University \\ Kaohuang, Taiwan \\ d964020002@student.nsysu.edu.tw
}

\begin{abstract}
Motivating people to contribute knowledge has become an important research topic and a major challenge for organizations. In order to promote knowledge sharing, managers need to understand the mechanism that drives individuals to contribute their valuable knowledge. Several theories have been applied to study knowledge-sharing behavior. However, the research settings and findings are often inconsistent. In this study, we use the social exchange theory as the basis to develop an extended model to explain knowledge-sharing behavior and include IT context as a moderator. A meta-analysis on 52 reported studies was conducted to examine how different factors in the social exchange theory affect knowledge-sharing behavior. The findings indicate that the social exchange theory plays an important role underlying individuals' knowledge-sharing behavior. The results also demonstrate that social interaction and trust can enhance individual's knowledge-sharing behavior. Furthermore, IT facilitation can moderate the effect of social interaction.
\end{abstract}

Keywords: Knowledge Sharing, Social Exchange Theory, Meta-Research, Knowledge Management 
Knowledge Sharing as Social Exchange: Evidence from a Meta-Analysis / Liu et al.

\section{Introduction}

Knowledge sharing is a core activity in organizational knowledge management (KM). However, effective knowledge sharing is not natural because people may consider their knowledge to be a valuable asset and are unwilling to share it. This is evidenced by a survey that indicated the biggest challenge organizations face with regard to knowledge management being "changing people's behavior," particularly with regard to knowledge sharing (Ruggles, 1998). Therefore, research on why people would share their knowledge and how to motivate people to share their knowledge are popular topics.

A few theories have been used to explain the knowledge sharing behavior, such as the Theory of Reasoned Action (Lin, 2007b) and the Social Exchange Theory. Among them, social exchange theory (SET) has received higher attention because knowledge sharing by nature is an activity of mutual exchange. SET views knowledge sharing behavior from the angle that people do it with an expectation of return benefits. Social psychologists Thibaut and Kelley (1959) argue that people engage in a social exchange because of their anticipated reciprocity, expected gain in reputation and influence on others, altruism and perception of efficacy and direct reward.

Although a large amount of studies have applied the social exchange theory to interpret knowledge sharing behavior, they tend to focus on a small set of selective factors. These studies may be conducted in different contexts or utilize different information technologies (such as in virtual communities, KM Systems or face-to-face meetings). For example, Kankanhalli et al. (2005) examined the effect of employees' knowledge self-efficacy and enjoyment in helping others on employees' knowledge contribution to electronic knowledge repositories. Ye et al. (2006) studied several social exchange factors such as reputation, reciprocity, knowledge selfefficacy, enjoyment in helping others, and commitment to explain knowledge contribution of virtual Community (VC) members. King and Marks (2008) investigated the effect of organizational support on employees' contribution frequency in traditional companies that used KM systems (KMS).

Different research settings cause another problem, that is, their findings may be inconsistent. Taking trust as an example, nine previous studies reported significant positive influences on individuals' knowledge-sharing behavior but five others reported insignificant relationship. This kind of inconsistency can be found on other social factors, such as organizational support, commitment, and social interaction. In an attempt to develop a more comprehensive social exchange model and clarify inconsistent findings in existing literature, this study classifies major factors that may affect knowledge sharing into three dimensions (individual cognition, interpersonal interaction, and organizational effort) and conducted a meta-analysis to consolidate their influences on individual's knowledgesharing behavior. Since the facilitation of information technology (IT) may play an important role, we include IT facilitation as a potential moderator. Hence, our research questions are as follows:

1. What are the effects of different social exchange factors on individuals' knowledgesharing behavior?

2. Whether the use of IT tools moderates the effect of these factors on knowledge sharing behavior?

In the next section, the social exchange theory and knowledge sharing are briefly introduced. This is followed by an explanation of our proposed research model and its variables. Then, the meta-analysis and the sample of this study are described. The findings from our meta-analysis are provided, and finally, the conclusion, implications and potential limitations are discussed.

\section{Theoretical Development}

The social exchange theory proposed by Blau in 1964 is a commonly used foundation for investigating individual's knowledge-sharing behavior. According to this theory, individuals interact with others based on a self-interest analysis of the costs and benefits of such an 
interaction. People seek to maximize their benefits and minimize their costs when exchanging resources with others (Molm, 2001). These benefits need not be tangible because individuals may engage in an interaction with the expectation of reciprocity (Gouldner, 1960). In such exchanges, people help others with the general expectation of some future returns, such as gaining desired resources through social reciprocity. In order to maximize the gained resources, individuals may build social relationships with others by sharing their knowledge.

Davenport and Prusak (1998) have outlined a few perceived benefits that may regulate people's knowledge sharing behavior, including future reciprocity, status, job security, and promotional prospects. From this perspective, knowledge sharing will be positively affected when an individual expects to obtain certain future benefits through reciprocation (Cabrera and Cabrera, 2005). Previous studies have reported quite a few factors related to the social exchange theory that can successfully explain knowledge-sharing behavior among individuals. They include personal cognition, interpersonal interaction, and organizational contexts. For example, Kankanhalli et al. (2005) argued that an individual's perceived benefit is one of the major factors that encourage employees to contribute knowledge to electronic knowledge repositories. According to Ma and Agarwal (2007), the amount of knowledge that people contribute to a virtual community depends on the level of satisfaction that they derive from being members of the community. Chiu et al. (2006) studied the effect of interpersonal factors such as social interaction, trust, and norm of reciprocity on knowledge sharing in VCs. Moreover, Kim and Lee (2006) have examined the organizational context for explaining knowledge sharing. Pai (2006) examined the role of top management support in the relationship between knowledge sharing and the use of IS/IT strategic planning. Watson and Hewett (2006) studied the effect of increased knowledge contribution within an organization.

Although the social exchange theory has been used successfully in explaining the be- havior of knowledge contributors, there is no comprehensive framework for classifying different factors and some existing findings are inconsistent. More specifically, the constructs used in some previous studies are diverse and contradictory findings on the same construct exist. In addition to the example of trust described in the introduction, the effect of organizational rewards on knowledge-sharing behavior is also inconsistent in different studies. Kim and Lee (2006) found that reward systems were significant in affecting employee knowledge-sharing capabilities. Lin (2007b), however, reported that organizational rewards did not have a significant effect on employees' willingness to share knowledge with their colleagues. These contradictory findings require further work to explicate the relationships.

In this section, we propose a framework that classify major factors into three categories, namely, individual cognition (intrinsic motivation and organizational commitment), interpersonal interaction (social interaction and trust), and organizational context (organizational support and reward systems). We also include IT context as a moderator in knowledge sharing.

\section{Individual Cognitions Factors}

Individual cognition is the first dimension in social exchange, which may include intrinsic motivation and organizational commitment. Intrinsic motivation refers to the motivation that makes people respond to an activity for its inherent enjoyment and satisfactions rather than for separable consequences (Ryan and Deci 2000). During social exchange, benefits of human behavior can be extrinsic or intrinsic in nature (Blau, 1967). People may choose to contribute their knowledge because they experience positive feelings of sociability (Wasko and Faraj, 2005). This positive feeling is a type of intrinsic reward, e.g., realizing one's complete personal and professional potential and feeling of pride when others use one's ideas (Cabrera et al., 2006). Osterloh and Frey (2000) found that intrinsic rewards are the most effective in facilitating the sharing of tacit knowledge. Thus, intrinsic 
Knowledge Sharing as Social Exchange: Evidence from a Meta-Analysis / Liu et al.

motivation may drive individuals to share their knowledge with others. Hence, our first hypothesis of social exchange is posited below.

H1a: Intrinsic motivation is positively associated with an individual's knowledgesharing behavior.

Organizational commitment is defined by O'Reilly and Chatman (1986) as the level and type of psychological attachment an individual has with an organization. It refers to a positive attitude toward the organization (Meyer and Allen, 1997; Mowday et al., 1982) and to the quality of the relationship between the individual and the organization. Organizational commitment has been found to be related to many organizational behaviors including turnover, job satisfaction, sense of obligation, and helpfulness (Meyer et al., 1993; O'Reilly and Chatman, 1986).

On the basis of shared membership, Wasko and Faraj (2005) proposed that one's commitment to a collective refers to a sense of responsibility to help others within that group. This may play an important role in encouraging an individual to share his or her knowledge. Results from prior research on the usage of KMS provide supportive evidence that organizational commitment is a strong determinant of individual engagement in knowledge sharing (van den Hooff and de Ridder, 2004; Cabrera et al., 2006). In an electronic network, an individual's commitment served as an important motivational factor for providing more helpful responses to others (Wasko and Faraj, 2005). Therefore, organizational commitment is considered to be the second major factor for the following hypothesis:

H1b: Organizational commitment is positively associated with an individual's knowledge-sharing behavior.

\section{Interpersonal Interaction}

"Exchange" in the social exchange theory refers to the actions of individuals in dyadic relations (Homans, 1958; Blau, 1964; Emerson, 1962). Interpersonal interaction is also a channel for information and resource flows (Tsai and Ghoshal, 1998). The more ex- change partners engage in interpersonal interactions, the greater is the intensity, frequency, and breadth of information exchanged (Larson, 1992). Thus, in addition to individual factors, interpersonal interaction is another dimension that may influence individuals' behavior of knowledge sharing. This study examines two popular interpersonal factors found in previous studies - social interaction and trust. Social interaction represents the strength of the relationships, the amount of time spent, and the frequency of communication among members. Hall (2003) stated that social interaction may lead to a series of exchange between parties. Nahapiet and Ghoshal (1998) argued that "network ties (social interaction) influence both access to parties for combining and exchanging knowledge and anticipation of value through such exchange." Furthermore, social interaction provides the opportunity to combine and exchange knowledge. Recent studies have also found empirical support for the influence of social interaction on individual's knowledge sharing (e.g., Chiu et al., 2006). This results in the following hypothesis:

H1c: Social interaction is positively associated with an individual's knowledgesharing behavior.

Trust refers to a set of specific beliefs primarily pertaining to the integrity, benevolence, and ability of another party (Chiu et al., 2006). In the social exchange theory, Blau (1964) argues that trust is essential for the social exchange process. Trust helps create and maintain exchange relationships. When trust exists between two parties, they are more willing to engage in cooperative interaction (Nahapiet and Ghoshal, 1998). Interpersonal trust is important in teams and organizations for creating an atmosphere for knowledge sharing (Nonaka, 1994). An important characteristic of informal interactions that should be noted is that individuals' contributions are difficult to evaluate. Therefore, trust is particularly important in volitional behaviors such as knowledge sharing in a VC (Chiu et al., 2006). Hence, we posit the following hypothesis. 
H1d: Trust is positively associated with an individual's knowledge-sharing behavior.

\section{Organizational Efforts}

The third group of factors that may affect knowledge sharing is organizational efforts in promoting such activities. Two organizational factors are common in KM research: organizational support and reward systems. Organizational support refers to the general perception that an organization cares for the wellbeing of its employees and values their contributions (Eisenberger et al., 1997). The social exchange perspective assumes that the relationship between employees and their employer is built on the trade of effort and loyalty for benefits such as pay, support, and recognition (van Knippenberg and Sleebos, 2006). Therefore, organizational support, direct or indirect, is an essential factor in the theory. Supervisor and coworker support is a subjective measure of the degree of encouragement provided to and experienced by an employee in sharing solutions for workrelated problems through the openness of communication, opportunity for face-to-face and electronic meetings to share knowledge, and so on. Therefore, our fifth hypothesis is as follows.

H1e: Organizational support is positively associated with an individual's knowledge-sharing behavior.

In addition to organizational support, reward systems that provide members with incentives to shape their behavior (Cabrera and Bonache, 1999) or improve their performance in learning (Pham and Swierczek, 2006) are also essential. Organizational rewards can range from monetary incentives such as increased salary and bonuses to nonmonetary rewards such as advanced promotions and other tangible rewards (Davenport and Prusak, 1998; Hargadon, 1998). Organizational rewards are typically performancebased and can improve employee motivation (Lee and Kim, 2001). In some cases, organizations may also frame their reward policies on the basis of employees' conduct (Pham and Swierczek, 2006). Hall (2001) explored the theme of incentives for knowledge sharing and classified rewards into explicit/hard rewards and soft rewards. In most existing studies, the explicit/hard rewards that organizations provide to motivate employees to share knowledge are more popular. These include pay increase, stock options, bonuses, promotion, and guarantee of future contracts. This leads to the hypothesis below.

H1f: Reward systems are positively associated with an individual's knowledgesharing behavior.

\section{The Moderating Role of Information Technology}

The term "IT facilitation" in this paper means whether contributors use information technology, such as information and communication technology (ICT), computer-mediated communication (CMC), knowledge repository, knowledge management systems (KMS), blogs and online forums in virtual communities, to support knowledge sharing. In fact, many organizations have already adopted some kinds of Knowledge Management System (KMS) or Information communication Technology (ICT) to facilitate knowledge sharing among organizational members (Davenport, 1997; Ruggles, 1998, O'Dell and Grayson, 1998). According to Yeh et al. (2006), IT facilitates effective knowledge management, including employees to share their knowledge, because ICT can provide communication channels for obtaining knowledge, correcting flow processes, and identifying the location of knowledge carriers and requesters. IT have the ability to overcome constraints of time and place, to retrieve and search for associated information, to reprocess and merge different contents, and to support many-to-many communication flows. Moreover, information systems can reduce the sharing costs and communication costs since sharing knowledge electronically incurs the same costs of codification, regardless if it is shared with one person or thousands of people (Jarvenpaa and Staples 2000). IT expands the scope of the potential audience, increasing the status and reputation benefits gained through sharing with 
Knowledge Sharing as Social Exchange: Evidence from a Meta-Analysis / Liu et al.

larger audiences (Wasko and Faraj, 2005). Generally speaking, information technology can stimulate knowledge sharing by reducing costs and increasing benefits (Sambamurthy and Subramani, 2005).

Albeit promising, information technologies create challenges for knowledge sharing. Several research has found that IT usage may not significantly influence organizational members' willingness to contribute knowledge (Van Den Hooff et al., 2004; Gottschalk and Solli-Sather, 2007; Lin 2007a). A possible reason is that IT offers limited opportunities for truly "social" communication (van den Hooff and de Ridder, 2004). Security and privacy may be other concerns. Information technologies, such as $\mathrm{CMC}$, are considered as the "lean" electronic media (Carlson and Zmud 1999). It provides lower social cues compared to face-to-face (F2F) that can provide continuous feedback during the interaction, using various social cues and body languages, and enabling unpredictable and spontaneous remarks. Due to reduced social context cues and the utilization of "leaner" communication media, the communication efficiency and team outcomes may decrease if IT is used to facilitate knowledge sharing. Some empirical evidence also suggests that facilitating shared understanding and resolving complex issues may be more difficult over IT. For example, Warkentin et al. (1997) found that it takes more time and effort by group members to achieve the same level of mutual understanding in CMCs, than in faceto-face communication. Since individuals have to codify their knowledge before sharing, the effort and time for communication increase in an IT environment, which may hinder knowledge sharing.

For a better view of the role of IT in knowledge sharing, van den Hooff et al. (2003) suggested researchers to consider the effect of IT together with other influences, such as identification, commitment and trust. Several studies indicated that IT context can provide a valuable backdrop for interpreting research on knowledge sharing. For example, Kankanhalli et al. (2005) reported that the impact of factors that influence an individual's knowledge sharing decision appears to be moderated by contextual factors. The study of DiGangi et al. (2012) comparing ComputerMediated Communication (CMC) to face-toface (F2F) environments also reported that the effect of different factors influencing knowledge sharing may vary in different contexts. Thus, it seems interesting to explore whether the IT context could moderate the effect of social exchange factors in knowledge sharing.

\section{Moderating effects on individual cognition}

IT facilitation of knowledge sharing has a number of characteristics, such as anonymity, lack of social cues and absence of status differences, which lead to producing more ideas and greater equality of participation (Bordia, 1997). Past literature (Weisband, 1992; Bordia, 1997) indicates that discussion in CMC groups has less interpersonal or social pressure. Intrinsic motivation may be strengthened when an individual has the feeling of being free and relaxed vs. coerced and pressured. It implies that an individual is more likely to engage in a particular behavior when the person feels free from pressure (Deci and Ryan, 1985). Therefore, with IT facilitation, intrinsic motivation may have a stronger effect on knowledge sharing.

Furthermore, differential benefits may be perceived when knowledge sharing occurs in online and F2F environments. As opposed to F2F environments, CMCs often do not possess assurances of direct reciprocal behavior from the original information seeker (Constant, et al., 1996). That is, individuals may lower their expectation of direct reciprocity when they share knowledge in an IT-based environment (DiGangi et al., 2012). Intrinsic motivation becomes more important under situations without external benefits. Thus, the following hypothesis is posited:

H2a: The effect of intrinsic motivation on knowledge sharing behavior will be stronger in an IT-facilitated environment.

From the other perspective, a considerable amount of research gas suggested that in- 
formation and communication are important antecedents of commitment (Foy, 1994; Meyer and Allen, 1997; Postmes et al., 2001). Commitment is a collectivistic motivator that drives people to care more for the whole community or their moral obligations and, thereby, pay less attention to self-benefits and risks. Furthermore, van den Hooff and de Ridder (2004) found that CMC use could positively influence affective commitment because the specific characteristics of CMC (such as reduced social cues and asynchronous communication) and lead to socially 'richer' communication, stronger identification with the group and more collective behavior. These findings imply that organizational commitment may have stronger influence for an individual to engage in knowledge sharing in an IT environment (e.g. CMC, ICT) vis-àvis the Face-to-Face environment. Thus, the following hypothesis is posited:

H2b: The effect of organizational commitment on knowledge sharing behavior will be stronger when IT facilitation exists.

\section{Moderating Effects on Interpersonal Inter- action}

ICT has the ability to overcome barriers of space and time. This feature can lead to more social interaction, stronger identification with the group and more collective behavior as knowledge sharing (Walther, 1996). CMC provides great convenience for easy and frequent contacts with others, which are helpful to build up shared practice and shared visions in a community. Since shared practice and visions are a ground for identification (Brown and Duguid, 2001; Scarbrough and Swan, 2001) and are useful for forming a "common identity" with which members can identify (Postmes and Spears, 2000), we project a positive effect of using ICT to identification with the community. Since past research has indicated that identification positively influences community members' ability and willingness to share knowledge (van den Hooff et al. 2003), the following hypothesis can be posited:
H2c: The effect of social interaction on knowledge sharing behavior will be stronger when IT facilitation exists.

Comparing with F2F meeting, IT-based KM systems can efficiently store and disseminate knowledge to a large population. This implies that shared knowledge is easily transferable to other unknown individuals with IT facilitation, which may increase the perceived risks associated with knowledge sharing. For example, Robert Jr. et al. (2009) found that perceived risk will increase when individuals shared in an ICT-mediated environment. Individuals may be reluctant to share knowledge because they feel that contributing valuable knowledge reduces their unique value, power and job security in an organization. In addition, relationship conflict was found to have a stronger negative influence on group potency in CMC groups than in face-to-face groups. Managing the divergence and multiplicity of opinions and interpretations is more difficult over CMC when conflict among members is present. In this case, trust becomes an important factor in a CMC environment.

A number of studies have claimed that ICT will enhance the degree of trust among people. For example, Jarvenpaa and Leidner (1999) argue, virtual teams that interact through ICT can very well develop trust. Burgoon et al. (2003) reported that participants who communicated exclusively through electronic communication were able to establish trust without meeting face-to-face. Our position here is that trust among knowledge contributors evolves to overcome barriers of perceived risks and relationship conflict. Thus, the following hypothesis is posited:

H2d: The effect of trust on knowledge sharing behavior will be stronger when IT facilitation exists.

\section{Moderating Effects on Organizational Ef- forts}

Another feature (or limitation) of CMC is that it takes more effort in the communication process as compared with the F2F communication. It takes longer to type and transmit a message under a CMC condition (Lebie et al. 
Knowledge Sharing as Social Exchange: Evidence from a Meta-Analysis / Liu et al.

1996). Findings also indicate that CMC groups need time to learn new medium and technology. Knowledge possessors may incur difficulties when they use new technologies for sharing, especially for older workers with less computer experience (Laguna and Babcock, 1997). Users may become frustrated with $\mathrm{CMC}$, and they react by lowering their evaluations on the technology. Their computer anxiety may increase when the organizations implement IT-based KM systems for knowledge sharing. In such conditions, support from top management and colleagues can reduce their anxiety and enhance their self-efficacy (Shih and Huang, 2009). The study of van den Hooff et al. (2003) indicated that computer comfort and self-efficacy positively influences the extent to which a member of a community uses ICT to share knowledge with other members. Organizational support also reduces user resistance when new information systems are introduced (Adams et al., 2004; Kim and Kankanhalli, 2009). That increases the likelihood that users will accept KMS for knowledge sharing. Thus, the following hypothesis is posited:
H2e: The effect of organizational support on knowledge sharing behavior will be stronger when IT facilitation exists.

The cost of knowledge sharing may differ between F2F and CMC environments. The social exchange theory states that Individuals weigh their expected cost and expected benefit in their social acts. As more efforts are required for knowledge sharing In an ITbased environment, people may be less willing to contribute their knowledge without appropriate tangible rewards from organizations. Therefore, we can anticipate that reward systems will have a stronger effect in motivating knowledge sharing behavior in the CMC environment. Thus, the following hypothesis is posited:

H2f: The effect of reward systems on knowledge sharing behavior will be stronger when IT facilitation exists.

To put together all the above hypotheses, our research model and hypotheses are illustrated in Figure 1.

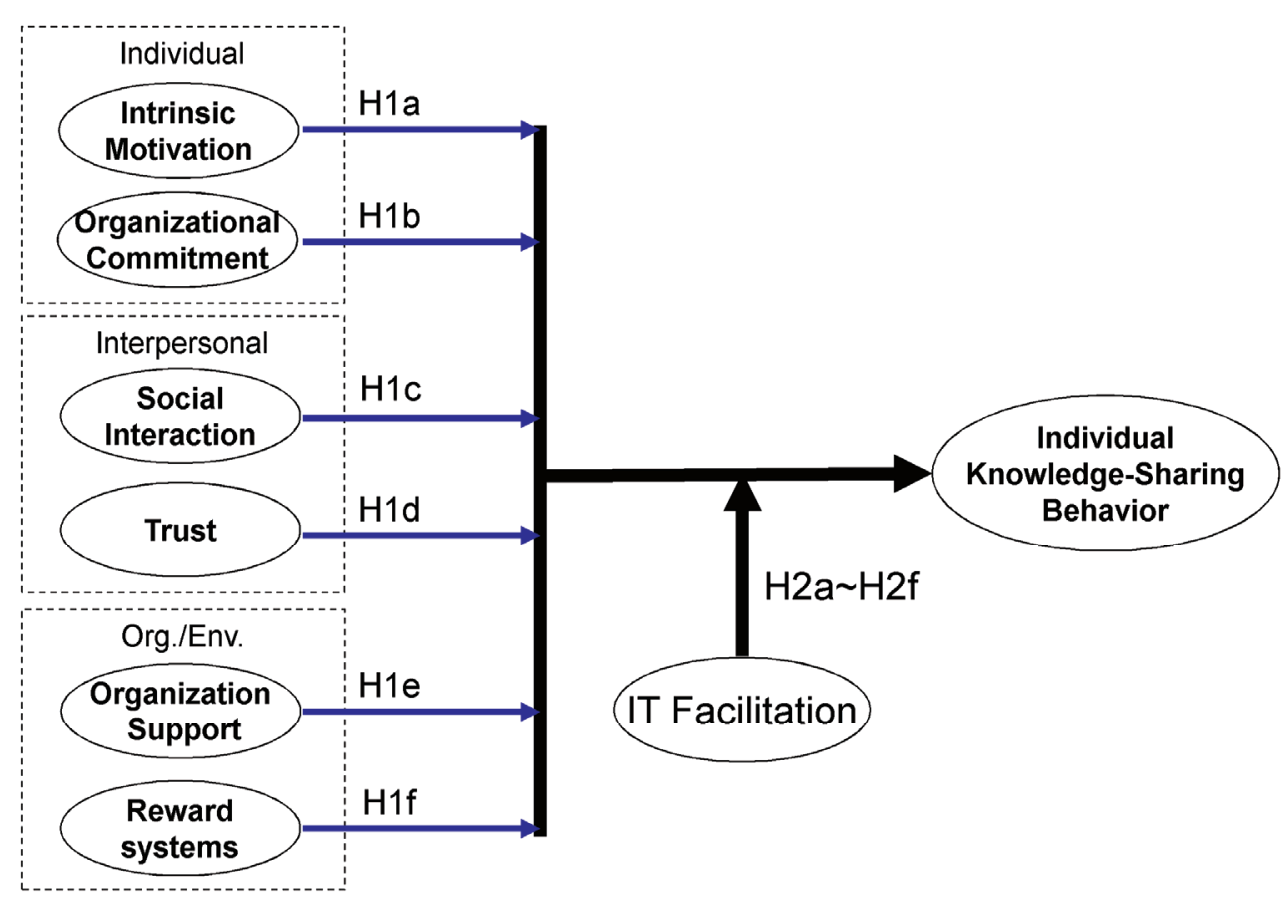

Figure 1 - Research Model and Hypotheses 


\section{Research Methodology}

In order to test the hypotheses, we conducted a meta-analysis to analyze data reported from previous literature. Meta-analysis is a technique that enables researchers to collect data from multiple previous studies in order to draw valid conclusions and explain variability in findings across multiple studies. The metaanalysis techniques employed in this study are similar to those employed in prior IS studies (e.g., Alavi and Joachimsthaler, 1992; Dennis et al., 2001; Kohli and Devaraj, 2003; Sharma and Yetton, 2003, 2007; Sabherwal et al., 2006).

We followed the procedure suggested in Sabherwal et al. (2006), which includes data collection (identifying the individual studies to be included in the analysis), variable measurement (coding individual studies), and data analysis (accumulating the findings reported by individual studies).

\section{Data Collection}

The sample of this meta-analysis consists of empirical studies reported in scholarly/peerreviewed journals and conference proceedings but omits unpublished dissertations and working papers. Following Hunter and Schmidt (2004) and Sharma and Yetton (2007), studies were located through multiple literature searches, including bibliographic databases such as ABI/INFORM, Emerald, Science Direct, and EBSCOhost. The databases were searched using the following multiple keywords: "knowledge sharing", "knowledge contribution", "knowledge distribution", "information sharing", and "information distribution". All keywords were searched on titles, author's keywords, or abstracts of papers. The initial search produced 2,546 items.

Studies were selected for inclusion in the meta-analysis only if they satisfied the following three criteria. First, they had to be empirical and had to report the correlation between knowledge-sharing behavior and the independent variables in this study. Second, they had to provide adequate descriptions of the sharing environment and/or IT tools used.
Third, in case the same study was reported in multiple papers, only one of them was selected to avoid overweighting. This screening process resulted in 164 studies published between 1994 and November 2010. The most common reasons for excluding a study were lack of adequate empirical data for the metaanalysis.

Papers published in peer-reviewed conference proceedings were included in order to alleviate the potential problem of favoring studies with statistically significant results over studies with insignificant results (Cooper and Hedges, 1994). The conference proceedings included in the study were ICIS, AMCIS, PACIS, HICSS, and ECIS. The search process yielded 44 conference papers.

Since different studies often adopt different variables or define the same variable differently, the resulting papers were further screened by two criteria: (1) whether the study is on the individual level behavior, and (2) whether variables are defined in a comparable way. After carefully reading and coding the selected papers, 51 articles remained for our final meta-analysis. Among them, 34 were journal articles and 17 were conference papers. One of the journal articles included two separate data sets that are considered two different studies for the purpose of our meta-analysis. The total sample size for our study was 52 . Table 1 lists the studies included in the meta-analysis and their IT facilitation.

\section{Variable Measurements and Coding}

Independent and dependent variables were properly coded to fit our research constructs. Two researchers coded each paper independently. Any inconsistency in coding was discussed and reviewed by the third researcher. Key concepts of each study were identified. Similar concepts were then grouped into a construct. The coding of each variable is explained below.

(1) Intrinsic motivation

Intrinsic motivation was defined as "doing something because it is inherently interesting or enjoyable" (Ryan and Deci, 2000). Deci 
Knowledge Sharing as Social Exchange: Evidence from a Meta-Analysis / Liu et al.

and Ryan (1985) stated that intrinsic motivation is also influenced by three innate psychological needs (i.e. autonomy, competence, and relatedness). Thus, this construct includes intrinsic rewards, satisfaction, enjoyment, autonomy, competence, and selfefficacy.

\section{(2) Organizational Commitment}

Organizational commitment was defined by most researchers as employees' attitude toward their job and attachment to and involvement in the organization. Commitment represents a duty or obligation to engage in future action and arises from frequent interaction (Coleman, 1990). Van Knippenberg and Sleebos (2006) identified three types of commitments: (1) continuance commitment from necessity, (2) normative commitment from obligation, and (3) affective organizational commitment from emotional attachment to and involvement. In this study, data on individuals' commitment to an organization, team, or other persons were put under this construct.

\section{(3) Social Interaction}

Social interaction represents the strength of the relationships, the amount of time spent, and the frequency of communication among members (Chiu et al., 2006). The measurement includes mutual understanding, influence, communication, and reciprocity with each other. It also includes individual's social skill, connection and network.

\section{(4) Trust}

Trust is defined as "the willingness of a party to be vulnerable to the actions of another party based on the expectation that the other party will perform a particular action important to the truster, irrespective of the ability to monitor or control that other party." (Mayer et al., 1995). McAllister (1995) classified two types of trust: (1) cognition-based trust: a rational evaluation of an individual's ability to carry out obligations; (2) affect-based trust: an emotional attachment that stems from mutual care and concern that exist between individuals. The measurements of individuals' trust in their organizations, teams, or other persons were included in this construct.

\section{(5) Organizational Support}

Organizational support is defined as a global belief concerning the extent to which an organization values employee contributions and cares about their well-being (Eisenberger et al., 1986). Organizational support describes the quality of the employee-organization relationship as indexed by an employee's perception of commitment and support from top management, supervisors, and coworkers, either directly or indirectly (Kulkarni et al., 2006). Lu et al. (2006) identified two major aspects of organizational support. First, the organizational context provides opportunities for employees to interact with each other and individuals have different degrees and nature of interpersonal relationships. Second, organizations have the authority to take steps to achieve specific goals as well as to provide resources to support or inhibit certain employee actions. Therefore, we included both types of formal support (e.g. train) and informal sanction, and help from top management, supervisors, and coworkers.

\section{(6) Reward Systems}

Reward systems are incentives that the organization provides to its members for shaping their behavior (Cabrera and Bonache, 1999) or improving their performance (Lee and Kim, 2001). Organizational rewards are typically based on performance measurement so that organizations can improve employee motivation (Lee and Kim, 2001). Some firms' reward policies are also based on processes and behaviors and not only outcomes (Pham and Swierczek, 2006). Organizational rewards found in sample studies ranging from monetary incentives, such as increased salary and bonuses, to nonmonetary awards, such as promotions, advancement, and other tangible rewards (Davenport and Prusak, 1998; Hargadon, 1998). In our study, we focus on the extrinsic rewards that organizations provide to motivate employees or members to share knowledge. The constructs include reward, incentives, promotion, and advancement, but excludes "intrinsic reward." 


\section{(7) Knowledge-sharing Behavior}

Knowledge-sharing behavior was defined as the degree to which one actually shares one's knowledge with other persons, groups, or organizations. In previous studies, researchers used various variables to measure knowledge-sharing behavior, such as frequency, quantity, time spent on knowledge sharing (King and Marks, 2008; Chiu et al., 2006; Burgess, 2005; Wasko and Faraj, 2005). Some other research focused on different receivers, such as external customers (Chen and Barnes, 2006) and team members (Renzl, 2008) or individuals sharing taskrelevant ideas, information, and suggestions with each other (Ferrin and Dirks, 2003). We also include knowledge sharing as the process in which individuals mutually exchange implicit and explicit knowledge (van den Hooff et al., 2003; Yuan et al., 2007).

\section{(8) Moderating Variable: IT Facilitation}

Regarding IT facilitation, we classified the sample by whether a particular study adopted an IT-based tool for knowledge sharing (i.e. Using IT or non-IT). The last column in Table 1 shows the classification of our sample.

To ensure consistency in coding, we designed a coding sheet and formulated coding rules (e.g., preference for multi-item measures over single-item measures). Initially, two researchers coded the selected papers independently. The researcher identified variables in their research model, contexts, and the relevant statistics (including correlations, reliabilities, and sample sizes) and the IT context. The coding results were then compared and disagreements were resolved through discussion. A total of 175 usable relationships were identified and coded from the 52 studies for testing the six pairwise relationships in our research model.

The descriptive statistics of the sample are shown in Table 2. As we can see, some relationships have been studied more extensively than others. For instance, the number of instances that investigates the relationships between intrinsic motivation (IM) and knowledge-sharing behavior (KSB) and be- tween social interaction ( $\mathrm{SI}$ ) and KSB is 37 and 40 , respectively, while the number of instances that investigates the relationship between organizational commitment and KSB is only 16 . The range of correlation coefficients also varies substantially. For example, the correlation between social interaction (SI) and KSB varied from -0.15 to 0.652 . The sample sizes of the selected studies vary from 34 to 824.

\section{Results \\ Correlation Analysis}

We followed the guidelines of Hunter et al. (1982) in making statements on the overall significance of each pairwise relationship. First, the sample size-adjusted correlation was calculated. Then, the mean was corrected for attenuation, since the effect of the measurement error could attenuate the correlation coefficient. In other words, the error of measurement could systematically lower the correlation between variables -- the true population effect size. In most studies, coefficient alpha is used as an estimator for the measurement reliability of variables - a practice also adopted in our study. The statistical significance of the correlations was deduced by the combined $Z$ scores for each construct. Further, we tested the significance of our findings. The fail-safe $\mathrm{N}$ statistic was calculated for every pairwise relationship to provide the number of insignificant correlations (studies) that would have to be included in the sample to reverse the conclusion that a significant relationship exists.

Based on Rosenthal's (1991) suggestion, the significant threshold of fail-safe $\mathrm{N}$ in the $95 \%$ confidential level is $\mathrm{Nfs}>5{ }^{*} \mathrm{k}+10$, where $\mathrm{Nfs}$ is the fail-safe $\mathrm{N}$ and $\mathrm{k}$ is the total number of studies in each pairwise relationship. The results shown in Table 3 indicate that all combined $Z$ scores are significant $(p<0.001)$. However, the pairwise relationships between organizational support and knowledgesharing behavior do not clear the file-drawer test at the 0.05 level, since fail-safe $N(104.00)$ is less than the threshold (135). All other pairwise relationships cleared the test and 


\begin{tabular}{|c|c|c|c|}
\hline Author(s) & $\begin{array}{l}\text { Journal or } \\
\text { Conference }\end{array}$ & Tools of Knowledge Sharing & $\begin{array}{c}\text { IT } \\
\text { Facilitation } \\
\end{array}$ \\
\hline Bakker et al. (2006) & Journal & No mention of using KMS or online sharing in the article & Non-IT \\
\hline Bartol et al. (2009) & Journal & No mention of using KMS or online sharing in the article & Non-IT \\
\hline Burgess (2005) & Journal & No mention of using KMS or online sharing in the article & Non-IT \\
\hline Cabrera et al. (2006) & Journal & Knowledge management systems & Using IT \\
\hline Cai and Xu (2008) & Conference & No mention of use KMS or online sharing in the article & Non-IT \\
\hline Chai et al. (2008) & Conference & blogs & Using IT \\
\hline Chang (2008) & Conference & $\begin{array}{l}\text { messages on electronic forums and documents in } \\
\text { online repositories }\end{array}$ & Using IT \\
\hline Chang et al. (2009) & Conference & No mention of use KMS or online sharing in the article & Non-IT \\
\hline Chiu et al. (2006) & Journal & BlueShop (IT-oriented virtual community) & Using IT \\
\hline Ferrin and Dirks (2003) & Journal & Group Problemsolving Software & Using IT \\
\hline Foss et al. (2009) & Journal & No mention of use KMS or online sharing in the article & Non-IT \\
\hline Gupta (2008) & Journal & No mention of use KMS or online sharing in the article & Non-IT \\
\hline $\begin{array}{l}\text { Hernandez and dos } \\
\text { Santos (2010) }\end{array}$ & Journal & No mention of use KMS or online sharing in the article & Non-IT \\
\hline Ho and Chang (2009a) & Conference & workgroup wikis & Using IT \\
\hline Ho and Chang (2009b) & Conference & email & Using IT \\
\hline Ho et al. (2010) & Conference & KMS & Using IT \\
\hline Hsu et al. (2007) & Journal & $\begin{array}{l}\text { discussion forum of Yahoo! Groups and professional } \\
\text { associations }\end{array}$ & Using IT \\
\hline $\begin{array}{l}\text { Ibragimova and Ryan } \\
\text { (2008) }\end{array}$ & Conference & No mention of use KMS or online sharing in the article & Non-IT \\
\hline $\begin{array}{l}\text { Jacobs and Roodt } \\
(2007)\end{array}$ & Journal & No mention of use KMS or online sharing in the article & Non-IT \\
\hline Kim and Lee (2006) & Journal & $\begin{array}{l}\text { knowledge-management systems in selected organiza- } \\
\text { tions }\end{array}$ & Using IT \\
\hline King and Marks (2008) & Journal & $\begin{array}{l}\text { knowledge management system in a large US federal } \\
\text { agency }\end{array}$ & Using IT \\
\hline $\begin{array}{l}\text { Kroumova and Laza- } \\
\text { rova }(2009)\end{array}$ & Journal & No mention of use KMS or online sharing in the article & Non-IT \\
\hline Lee and Kim (2001) & Conference & enterprise-wide KMS & Using IT \\
\hline Liao (2006) & Journal & No mention of use KMS or online sharing in the article & Non-IT \\
\hline Liao (2008) & Journal & No mention of use KMS or online sharing in the article & Non-IT \\
\hline Lin (2007a) & Journal & No mention of use KMS or online sharing in the article & Non-IT \\
\hline Lu et al. (2006) & Journal & $\begin{array}{l}\text { IT (organizational databases, e-mail and online chat- } \\
\text { rooms, Web page or bulletin board systems, electronic } \\
\text { document management systems, and specialized KM } \\
\text { software) }\end{array}$ & Using IT \\
\hline $\begin{array}{l}\text { Ma and Agarwal (2007) } \\
\text { study } 1\end{array}$ & Journal & Online community (Quitnet.com) & Using IT \\
\hline $\begin{array}{l}\text { Ma and Agarwal (2007) } \\
\text { study } 2\end{array}$ & Journal & Online community (IS300.net) & Using IT \\
\hline
\end{tabular}


Knowledge Sharing as Social Exchange: Evidence from a Meta-Analysis / Liu et al.

\begin{tabular}{|c|c|c|c|}
\hline $\begin{array}{l}\text { Marett and Joshi } \\
(2009)\end{array}$ & Journal & an online discussion forum & Using IT \\
\hline $\mathrm{Ng}$ and Butts (2009) & Journal & No mention of use KMS or online sharing in the article & Non-IT \\
\hline Noor et al. (2005) & Conference & $\mathrm{C} 2 \mathrm{C}$ tourism website & Using IT \\
\hline $\begin{array}{l}\text { Pham and Swierczek } \\
(2006)\end{array}$ & Journal & No mention of use KMS or online sharing in the article & Non-IT \\
\hline Phang et al. (2009) & Journal & discussion forum system & Using IT \\
\hline Quigley et al. (2007) & Journal & $\begin{array}{l}\text { CELCOM } 21 \text { (computer-based interactive management } \\
\text { decision-making simulation) }\end{array}$ & Using IT \\
\hline Renzl (2008) & Journal & No mention of use KMS or online sharing in the article & Non-IT \\
\hline $\begin{array}{l}\text { Reychav and Weisberg } \\
(2009)\end{array}$ & Journal & No mention of use KMS or online sharing in the article & Non-IT \\
\hline Shen et al. (2009) & Conference & wiki communities (Baidu Baike and Hudong) & Using IT \\
\hline Shen et al. 62 (2007) & Conference & four different virtual communities & Using IT \\
\hline $\begin{array}{l}\text { Staples and Webster } \\
(2008)\end{array}$ & Journal & No mention of use KMS or online sharing in the article & Non-IT \\
\hline $\begin{array}{l}\text { Taylor and Murthy } \\
(2009)\end{array}$ & Journal & ENOP (similar to a bulletin board) & Using IT \\
\hline $\begin{array}{l}\text { van den Hooff and de } \\
\text { Ridder (2004) }\end{array}$ & Journal & Computer-Mediated Communication tools & Using IT \\
\hline Wang and Lai (2006) & Journal & No mention of use KMS or online sharing in the article & Non-IT \\
\hline $\begin{array}{l}\text { Wasko and Faraj } \\
(2005)\end{array}$ & Journal & a Web-based system & Using IT \\
\hline $\begin{array}{l}\text { Watson and Hewett } \\
(2006)\end{array}$ & Journal & four proprietary knowledge repositories & Using IT \\
\hline $\begin{array}{l}\text { Willem and Buelens } \\
(2007)\end{array}$ & Journal & No mention of use KMS or online sharing in the article & Non-IT \\
\hline Wu and Sukoco (2010) & Journal & No mention of use KMS or online sharing in the article & Non-IT \\
\hline Wu et al. (2006) & Conference & $\begin{array}{l}\text { Cyber University (asynchronous network learning sys- } \\
\text { tem) }\end{array}$ & Using IT \\
\hline Ye et al. (2010) & Conference & No mention of use KMS or online sharing in the article & Non-IT \\
\hline Yu et al. (2010) & Conference & No mention of use KMS or online sharing in the article & Non-IT \\
\hline Yuan et al. (2007) & Conference & $\begin{array}{l}\text { Coordination technology(Software configuration man- } \\
\text { agement, project status, notification services, project } \\
\text { scheduling and tasking, CASE and process manage- } \\
\text { ment, programming tools, bug and change tracking, } \\
\text { team memory \& knowledge center) }\end{array}$ & Using IT \\
\hline Zheng and Kim (2007) & Conference & cyworld.com (Virtual Community) & Using IT \\
\hline
\end{tabular}

\section{Table 2 - Descriptive statistics}

\begin{tabular}{|c|c|c|c|c|c|c|c|c|}
\hline \multirow{2}{*}{$\begin{array}{c}\text { Pairwise } \\
\text { Relationship }\end{array}$} & $\begin{array}{c}\text { No. of } \\
\text { Studies } \\
(\mathbf{k})\end{array}$ & \multirow{2}{*}{ Variance } & \multicolumn{2}{|c|}{$\begin{array}{c}\text { Range of } \\
\text { Correlations }\end{array}$} & $\begin{array}{c}\text { Range of Sample } \\
\text { Sizes }\end{array}$ & $\begin{array}{c}\text { Cumulative } \\
\text { Sample } \\
\text { Size }\end{array}$ & $\begin{array}{c}\text { Average } \\
\text { Sample Size }\end{array}$ \\
\cline { 4 - 9 } & & Lower & Upper & Lower & Upper & & \\
\hline IM - KSB & 37 & 0.0217 & -0.04 & 0.6446 & 47 & 718 & 9,071 & 245 \\
\hline OC - KSB & 16 & 0.0343 & 0.11 & 0.7161 & 69 & 718 & 4,722 & 295 \\
\hline SI -KSB & 40 & 0.0501 & -0.15 & 0.652 & 34 & 500 & 9,748 & 244 \\
\hline TR -KSB & 32 & 0.058 & -0.05 & 0.7291 & 43 & 824 & 8,008 & 250 \\
\hline OS -KSB & 25 & 0.0203 & -0.03 & 0.54 & 169 & 430 & 5,959 & 238 \\
\hline RS -KSB & 25 & 0.0457 & -0.1 & 0.625 & 68 & 480 & 6,427 & 257 \\
\hline
\end{tabular}


Knowledge Sharing as Social Exchange: Evidence from a Meta-Analysis / Liu et al.

were good enough to conclude the significant results across studies. In other words, our findings in Table 3 support hypotheses $\mathrm{H} 1 \mathrm{a} \sim \mathrm{H} 1 \mathrm{f}$ with the exception of H1e. That is, on the basis of an aggregation of 52 studies, five social exchange factors were found to have a significant effect on KSB. The only inconclusive factor is organizational support.

\section{Moderating Analysis}

In order to investigate the moderating effect of IT facilitation, homogeneity estimates (Q) for each relationship were calculated based on the Hedges and Olkin (1985) procedure. This gives an indication of the possible moderating effects. $Q$ value, which is based on Fisher's $Z$ scores, is compared to a critical value, which is $\mathrm{X} 2$ for $\alpha=0.05$ and $\mathrm{k}-1 \mathrm{de}-$ grees of freedom ( $k$ being the number of studies). If $Q$ value exceeds the critical value, the hypothesis of the homogeneity of study effects is rejected and the heterogeneity of study effects suggests the presence of moderating variables.

The result shows that all six pairwise relationships fail the homogeneity test $(p<0.001)$. That is, moderators exist. We further divided the sample into different groups (as shown in the categories in Table 1) to separately test the effect of independent variables. The effect of IT support was examined by the difference between two groups: using IT $(\mathrm{k}=32)$ and non-IT $(k=20)$.
We applied three indices to test the significance of moderators. The moderating effect exists if the results in two groups differ. The average residual variance of groups was required to be less than the one in the combined samples (Hunter et al., 1982; Bausch and Krist, 2007). As a final step, we calculated t-statistics to test for significance of differences in effect sizes (Dennis et al., 2001). The moderating effect is concluded if two or more of the three tests support the existence of such an effect.

The result of the three indices for every pairwise relationship between the two groups is shown in Table 4. For the using IT facilitation group, four pairwise relationships (organizational commitment, social interaction, trust, and reward systems) cleared the test, but the other two (intrinsic motivation and organizational support) did not. In other words, IT facilitation can moderate the effect of organizational commitment, social interaction, trust, and reward systems on KSB. However, the influences of organizational commitment $(0.526$-->0.324) and trust (0.561-->0.348) on knowledge sharing behavior under different IT context reveals opposite results as we hypothesized. Therefore, we conclude that Hypotheses $\mathrm{H} 2 \mathrm{c}$ and $\mathrm{H} 2 \mathrm{f}$ are supported, but $\mathrm{H} 2 \mathrm{a}$ and $\mathrm{H} 2 \mathrm{e}$ are insignificant, and $\mathrm{H} 2 \mathrm{~b}$ and $\mathrm{H} 2 \mathrm{~d}$ are significant but the direction is opposite to the hypotheses and hence are considered to be unsupported.

\begin{tabular}{|c|c|c|c|c|c|}
\hline Table 3 - Correlation analysis \\
\hline $\begin{array}{c}\text { Hypotheses and } \\
\text { Pairwise Relationship }\end{array}$ & $\begin{array}{c}\text { True Population } \\
\text { Effect Size ( } \mathbf{r})\end{array}$ & $\begin{array}{c}\text { Combined Z } \\
\text { Scores }\end{array}$ & $\begin{array}{c}\text { Fail-safe N } \\
\mathbf{( p = 0 . 0 5 )}\end{array}$ & $\begin{array}{c}\text { Threshold of } \\
\text { Fail-safe N in } \\
\mathbf{0 . 0 5}\end{array}$ & $\begin{array}{c}\text { Hypothesis } \\
\text { Supported }\end{array}$ \\
\hline H1a: IM-KSB & 0.406 & $40.428^{* * *}$ & 195 & $263.52^{*}$ & Yes \\
\hline H1b: OC-KSB & 0.449 & $32.669^{* *}$ & 90 & $127.96^{*}$ & Yes \\
\hline H1c: SI-KSB & 0.317 & $32.229^{* * *}$ & 210 & $214.37^{*}$ & Yes \\
\hline H1d: TR-KSB & 0.431 & $40.656^{* * *}$ & 170 & $244.42^{*}$ & Yes \\
\hline H1e: OS-KSB & 0.258 & $20.256^{* *}$ & 135 & 104.00 & No \\
\hline H1f: RS-KSB & 0.32 & $27.173^{* * *}$ & 135 & $139.75^{*}$ & Yes \\
\hline
\end{tabular}




\begin{tabular}{|c|c|c|c|c|c|c|}
\hline $\begin{array}{c}\text { Hypotheses and } \\
\text { Pairwise } \\
\text { Relationship }\end{array}$ & $\begin{array}{c}\text { \# of } \\
\text { Instances }\end{array}$ & $\begin{array}{c}\text { True Effect } \\
\text { Size ( r) }\end{array}$ & $\begin{array}{l}\text { Significant } \\
\text { Difference }\end{array}$ & $\begin{array}{l}\text { Difference of } \\
\text { Residual } \\
\text { Variance }\end{array}$ & $\begin{array}{c}\text { p Value of } \\
\text { t-test } \\
(+: p<0.1)\end{array}$ & $\begin{array}{l}\text { Hypothesis } \\
\text { Supported }\end{array}$ \\
\hline $\begin{array}{l}\text { H2a: (Non-IT) } \\
\text { IM-KSB (IT) }\end{array}$ & $\begin{array}{l}18 \\
19\end{array}$ & $\begin{array}{l}0.415 \\
0.402\end{array}$ & $\begin{array}{l}\text { Yes } \\
\text { Yes }\end{array}$ & -0.00003 & 0.391 & No \\
\hline $\begin{array}{l}\text { H2b: (Non-IT) } \\
\text { OC-KSB (IT) }\end{array}$ & $\begin{array}{c}6 \\
10\end{array}$ & $\begin{array}{l}0.526 \\
0.324\end{array}$ & $\begin{array}{l}\text { Yes } \\
\text { No }\end{array}$ & 0.0117 & $0.008^{* *}$ & $\begin{array}{c}\text { No } \\
\text { (Opposite) }\end{array}$ \\
\hline $\begin{array}{l}\text { H2c: (Non-IT) } \\
\text { SI-KSB (IT) }\end{array}$ & $\begin{array}{l}10 \\
30\end{array}$ & $\begin{array}{l}0.244 \\
0.357\end{array}$ & $\begin{array}{l}\text { No } \\
\text { Yes }\end{array}$ & -0.00438 & $0.071+$ & Yes \\
\hline $\begin{array}{c}\text { H2d: (Non-IT) TR- } \\
\text { KSB (IT) }\end{array}$ & $\begin{array}{l}10 \\
22\end{array}$ & $\begin{array}{l}0.561 \\
0.348\end{array}$ & $\begin{array}{l}\text { Yes } \\
\text { Yes }\end{array}$ & 0.00413 & $0.009^{* *}$ & $\begin{array}{c}\text { No } \\
\text { (Opposite) }\end{array}$ \\
\hline $\begin{array}{l}\text { H2e: (Non-IT) } \\
\text { OS-KSB (IT) }\end{array}$ & $\begin{array}{l}11 \\
14\end{array}$ & $\begin{array}{l}0.217 \\
0.285\end{array}$ & $\begin{array}{l}\text { No } \\
\text { No }\end{array}$ & 0.00311 & 0.115 & No \\
\hline $\begin{array}{l}\text { H2f: (Non-IT) } \\
\text { RS-KSB (IT) }\end{array}$ & $\begin{array}{c}17 \\
8\end{array}$ & $\begin{array}{l}0.282 \\
0.414\end{array}$ & $\begin{array}{l}\text { No } \\
\text { Yes }\end{array}$ & 0.00166 & $0.069^{*}$ & Yes \\
\hline
\end{tabular}

\section{Discussion and Conclusion}

In this paper, we have reported findings from a meta-analysis on 52 published studies to examine social exchange factors and their effects on individuals' knowledge sharing behavior. Drawing on the social exchange theory and individual's knowledge sharing, this paper has two major contributions.

First, it demonstrates that, as predicted by the theory, social exchange factors were positively associated with knowledge sharing. The results indicate that most constructs in the social exchange theory (except organizational support) can explain an individuals' knowledge-sharing behavior. This confirms the role of social exchange as a key theory in interpreting individual's behavior in knowledge sharing. Organizational commitment has the highest correlation coefficient (0.449) among the social exchange factors. In interpersonal factors, trust is the strongest factor that makes an individual to share their knowledge with others.

An interesting observation is that the correlation between organizational support and individuals' knowledge-sharing behavior is not as significant as many would believe. One possible explanation is that the effect may be diluted by the heterogeneity of different types of organizational support including formal support (e.g., training) and informal sanction and help from top management, supervisors, and coworkers. While some types of organizational support may have an effect on knowledge-sharing, others may not. Another possibility is that task accomplishments and job security often take priority over knowledge sharing; hence, management support may affect employee attitude but its effect may not be strong enough to change behavior ( $\mathrm{Lu}$ et al., 2006; Bartol et al., 2009). Although we did not find significance for organizational support from previous studies, we cannot conclude that organizational support does not have any effect on knowledge-sharing behavior. Its actual impact requires further examination.

Second, this study explores the moderating role of IT facilitation, which has not received much attention in previous studies. We have found that IT facilitation has moderating effects on four factors - organizational commitment, social interaction, trust, and reward systems. The effects of organizational commitment and trust on knowledge sharing are stronger for the context of non-IT support while social interaction and reward systems are more important in IT facilitating environment. These results shed lights on our understanding of the role IT in knowledge contribution.

\section{Implications for Research}

This paper develops an extended social exchange model to consolidate inconsistent 
Knowledge Sharing as Social Exchange: Evidence from a Meta-Analysis / Liu et al.

findings in knowledge-sharing literature. The results have several important implications for future research. First, we have identified six major social exchange enablers and investigated their effects on knowledge sharing from three facets: personal cognition, relationships among members, and organizational effort. The results showed that most of these factors had significantly influences on individuals' behavior of knowledge sharing, which is consistent with the prediction of Social Exchange Theory. This extended model provides a useful framework for future research in the area.

Second, we have shown that contingent factors such as IT facilitation did moderate the knowledge-sharing behavior. As argued in the literature review, we need a way to explain some previously reported correlations between knowledge-sharing behavior and social exchange factors, such as external rewards of -0.10 (Cai and $\mathrm{Xu}, 2008$ ), -0.02 (Foss et al. 2009), and 0.10 (Burgess 2005) against values of 0.41 (Willem and Buelens, 2007), 0.52 ( $\mathrm{Ng}$ and Butts 2009), and 0.58 (Kim and Lee, 2006). Our model that includes IT facilitation as a moderator is an initial trial to explain these diverse findings. Our findings showed that the impacts of organizational commitment, social interaction, trust, and reward systems appear to be moderated by the contextual IT factor. Significant proportions of the variance in reported correlations are accounted for by the moderating effect of using IT to support knowledge sharing.

The other interesting findings, in contrast to what past studies had predict (van den Hooff and de Ridder 2004; Burgoon et al. 2003), appeared the results to be negative association between organizational commitment and trust to share knowledge in an IT-facilitated environment. This suggests that we need to consider contextual variables such as IT use more carefully in future research, especially in investigating knowledge sharing behavior.

\section{Implications for Practice}

The findings of this study can also help practitioners. First, our results confirmed that people anticipate returns from knowledge sharing. Therefore, management should provide ade- quate incentive programs to motivate knowledge contribution. These programs can focus on extrinsic rewards, such as better work assignment, promotion incentive, salary incentive, bonus incentive, or job security.

Second, the management may design a mechanism to enhance the social relationship of employees before launching the KM system. Our study shows that social interaction and trust are more effective for encouraging knowledge sharing in organizations with IT support than those without IT facilitation. However, less knowledge is shared by knowledge workers in the KMS if social relationships in the organization are weak. Thus, encouraging employees to create and maintain their social relationships is important for knowledge sharing.

Third, since knowledge sharing is a form of social exchange, intrinsic motivation is important for individuals to establish and continue the exchange of expertise and resources, especially in the context of online communities which members voluntarily contribute their knowledge without receiving monetary rewards (Lee and Cole, 2003). Managers can enhance members' intrinsic motivation through establishing their knowledge selfefficacy, providing more job autonomy, and encouraging their intention to help others.

Finally, enhancing organizational commitment and trust might be more effective for sharing intangible knowledge in a face-to-face mode. On the contrary, social interaction and extrinsic rewards may influence people to share their knowledge through IT-based KM system. Therefore, successful adoption of KMS may need more social interaction and carefully designed extrinsic reward systems.

\section{Limitations and Future Research}

The above conclusions are subject to a number of limitations, which also indicate opportunities for future research. First, this study examined only social exchange factors related to knowledge sharing. To focus on the perspective of social exchange, we did not use the dominant factors of other aspects as independent variables, such as personality 
traits (Cabrera et al., 2006; Hsu and Lin, 2008) and social identity (Lin, 2007a; Ma and Agarwal, 2007). Because of the nature of meta-research and limitations of data availability, a comprehensive study to include all potential factors is not feasible at this point. Future research may examine those factors excluded in this study.

Second, the study focuses on the social exchange aspect of knowledge sharing. Hence, other theories relevant to knowledge sharing behaviors, such as social capital (Kankanhalli et al., 2005; Chiu et al., 2006), are not examined. Future research may examine them or compare them with the social exchange theory.

Third, we have observed the existence of moderators and investigated the moderating effect of IT facilitation. Other potential moderators, such as culture (Griffith et al., 2006), knowledge type (Lu et al., 2006), and performance-related competition (Wang, 2004), may also worth investigation. It would be beneficial to conduct additional research to find their roles in knowledge sharing. There are multiple ways to operationalize IT facilitation. In our study, we divided it into two levels -- using or not using IT to facilitate knowledge sharing, without considering the functional differences of the knowledge management

\section{References}

Adams, B., Berner, E., and Wyatt, J. R. (2004). "Applying Strategies to Overcome User Resistance in a Group of Clinical Managers to a Business Software Application: A Case Study," Journal of Organizational and End User Computing, 16(4), pp.55-64.

Alavi, M., and Joachimsthaler, E. A. (1992). "Revisiting Dss Implementation Research: A Meta- Analysis of the Literature and Suggestions for Researchers," MIS Quarterly, 16(1), pp.95-116.

Bartol, K. M., Liu, W., Zeng, X., and Wu, K. (2009). "Social Exchange and Knowledge Sharing among Knowledge Workers: The Moderating systems in different studies. Whether different IT functions can result in different knowledge sharing behavior is an issue that needs further study.

Finally, the findings of the study may also be limited by the coding procedure. A metaresearch is targeted at drawing together previous research and correcting for sampling error in individual studies (Hunter and Schmidt, 1990). Since different studies may define constructs differently, it is likely that the aggregation process leads to misclassification of relationships and hence result in wrong conclusions. For example, communication frequency and quality could be coded into two different constructs or a single one. Different coding certainly could lead to different results. Although we have taken all possible precautions to ensure proper coding, inherent limitations of the meta-analysis method always exist.

\section{Acknowledgements}

This research was partially supported by a project from National Science Council under contract number NSC96-2752-H110-003$\mathrm{PAE}$. An earlier version of the paper was presented at the 2008 International Conference on Information Systems.

Role of Perceived Job Security," Management and Organization Review, 5(2), pp.223-240.

Bausch, A., and Krist, M. (2007). "The Effect of Context-Related Moderators on the Internationalization-Performance $\mathrm{Re}$ lationship: Evidence from MetaAnalysis," Management International Review (MIR), 47(3), 2007 3rd Quarter, pp.319-347.

Blau, P. M. (1964). Exchange and Power in Social Life. Wiley: New York.

Bordia, P. (1997). "Face-to-Face Versus Computer-Mediated Communication: A Synthesis of the Experimental Liter- 
Knowledge Sharing as Social Exchange: Evidence from a Meta-Analysis / Liu et al.

ature," Journal of Business Communication, 34(1), pp.99-118.

Brown, J. S., and Duguid, P. (2001). "Knowledge and Organization: A Social-Practice Perspective," Organization Science, 12(2), pp.198-213.

Burgess, D. (2005). "What Motivates Employees to Transfer Knowledge Outside Their Work Unit?," Journal of Business Communication, 42(4), pp.324-348.

Burgoon, J. K., Stoner, G. M., Bonito, J. A., and Dunbar, N. E. (2003). "Trust and Deception in Mediated Communication," in: Proceedings of the 36th Annual Hawaii Int. Conference on System Sciences (HICSS 2003). Hawaii, USA.

Cabrera, Á., Collins, W. C., and Salgado, J. F. (2006). "Determinants of Individual Engagement in Knowledge Sharing," International Journal of Human Resource Management, 17(2), pp.245264.

Cabrera, E. F., and Bonache, J. (1999). "An Expert Hr System for Aligning Organizational Culture and Strategy," Human Resource Planning, 22(1), pp.51-60.

Cabrera, E. F., and Cabrera, A. (2005). "Fostering Knowledge Sharing through People Management Practices," International Journal of Human Resource Management, 16(5), pp.720-735.

Cai, S., and Xu, Y. (2008). "Voluntary Knowledge Sharing in Organizations," Proceedings of the 12th Asia Pacific Conference on Information Systems (PACIS 2008), Paper 59, Suzhou, China.

Carlson, J., and Zmud, R. (1999). "Channel Expansion Theory and the Experiential Nature of Media Richness Perceptions," Academy of Management Journal, 42(2), pp.153-170.

Chen, L. Y., and Barnes, F. B. (2006). "Leadership Behaviors and Knowledge
Sharing in Professional Service Firms Engaged in Strategic Alliances," Journal of Applied Management and Entrepreneurship, 11(2), pp.51-69.

Chiu, C.-M., Hsu, M.-H., and Wang, E. T. G. (2006). "Understanding Knowledge Sharing in Virtual Communities: An Integration of Social Capital and Social Cognitive Theories," Decision Support Systems, 42(3), pp.1872-1888.

Coleman, J. S. (1990). Foundations of Social Theory. Harvard University Press: Massachusetts.

Constant, D., Sproull, L., and Kiesler, S. (1996). "The Kindness of Strangers: The Usefulness of Electronic Weak Ties for Technical Advice," Organization Science, 7(2), pp.119-135.

Cooper, H. M., and Hedges, L. V. (1994). The Handbook of Research Synthesis. Russell Sage Foundation: New York.

Davenport, T. (1997). Information Ecology: Mastering the Information and Knowledge Environment. Oxford University Press: New York.

Davenport, T. H., and Prusak, L. (1998). Working Knowledge: How Organisations Manage What They Know. Harvard Business School Press: Boston, MA.

Deci, E. L., and Ryan, R. M. (1985). Intrinsic Motivation and Selfdeterminationin Human Behavior. Plenum Press Publishing Co.: New York.

Dennis, A. R., Wixom, B. H., and Vandenberg, R. J. (2001). "Understanding Fit and Appropriation Effects in Group Support Systems Via Meta-Analysis," MIS Quarterly, 25(2), pp.167-193.

DiGangi, P. M., Wasko, M., and Tang, X. (2012). "Would You Share? Examining Knowledge Type and Communication Channel for Knowledge Sharing within and across the Organizational Boundary," International Journal of 
Knowledge Management, 8(1), pp.pp.1-21.

Eisenberger, R., Cummings, J., Armeli, S., and Lynch, P. (1997). "Perceived Organizational Support, Discretionary Treatment, and Job Satisfaction," Journal of Applied Psychology, 82(5), pp.812-820.

Eisenberger, R., Huntington, R., Hutchison, S., and Sowa, D. (1986). "Perceived Organizational Support," Journal of Applied Psychology, 71(3), pp.500507.

Emerson, R. M. (1962). "Power-Dependence Relations," American Sociological Review, 27(1), pp.31-41.

Ferrin, D. L., and Dirks, K. T. (2003). "The Use of Rewards to Increase and Decrease Trust: Mediating Processes and Differential Effects," Organization Science, 14(1), pp.18-31.

Foss, N. J., Minbaeva, D. B., Pedersen, T., and Reinholt, M. (2009). "Encouraging Knowledge Sharing among Employees: How Job Design Matters," $\mathrm{Hu}$ man Resource Management, 48(6), pp.871-893.

Foy, N. (1994). Empowering People at Work. Gower: London.

Gottschalk, P., and Solli-Sather, H. (2007). "Computer Information Systems as Determinants of Police Investigation Performance: An Empirical Study," Journal of Computer Information Systems, 47(3), pp.45-59.

Gouldner, A. W. (1960). "The Norm of Reciprocity: A Preliminary Statement," American Sociological Review, 25(2), pp.161-178.

Griffith, D. A., Myers, M. B., and Harvey, M. G. (2006). "An Investigation of National Culture's Influence on Relationship and Knowledge Resources in Interorganizational Relationships between Japan and the United States," Journal of International Marketing, 14(3), pp.132.

Hall, H. (2001). "Input-Friendliness: Motivating Knowledge Sharing across Intranets," Journal of Information Science, 27(3), p.139.

Hall, H. (2003). "Borrowed Theory: Applying Exchange Theories in Information Science Research," Library \& Information Science Research, 25(3), pp.287-306.

Hargadon, A. B. (1998). "Firms as Knowledge Brokers: Lessons in Pursuing Continuous Innovation," California Management Review, 40(3), pp.209-227.

Hedges, L., and Olkin, I. (1985). Statistical Methods for Meta Analysis. Academic Press: Orlando, FL.

Homans, G. C. (1958). "Social Behavior as Exchange," The American Journal of Sociology, 63(6), pp.597-606.

Hsu, C.-L., and Lin, J. C.-C. (2008). "Acceptance of Blog Usage: The Roles of Technology Acceptance, Social Influence and Knowledge Sharing Motivation," Information \& Management, 45(1), pp.65-74.

Hunter, J. E., and Schmidt, F. L. (1990). Methods of Meta-Analysis: Correcting Error and Bias in Research Findings. Sage Publications: Newbury Park, CA.

Hunter, J. E., and Schmidt, F. L. (2004). Methods of Meta-Analysis: Correcting Error and Bias in Research Findings (2nd Ed.). Sage Publications: Newbury Park, CA.

Hunter, J. E., Schmidt, F. L., and Jackson, G. B. (1982). Meta-Analysis: Cumulating Research Findings across Studies. Sage Publications: Beverly Hills, CF.

Jarvenpaa, S. L., and Leidner, D. E. (1999). "Communication and Trust in Global Virtual Teams," Organization Science, 10(6), pp.791-815.

Jarvenpaa, S. L., and Staples, D. S. (2000). "The Use of Collaborative Electronic 
Knowledge Sharing as Social Exchange: Evidence from a Meta-Analysis / Liu et al.

Media for Information Sharing: An Exploratory Study of Determinants," Journal of Strategic Information Systems, 9(2-3), pp.129-154.

Kankanhalli, A., Tan, B. C. Y., and Kwok-Kee, W. (2005). "Contributing Knowledge to Electronic Knowledge Repositories: An Empirical Investigation," MIS Quarterly, 29(1), pp.113-143.

Kim, H. W., and Kankanhalli, A. (2009). "Investigating User Resistance to Information Systems Implementation: A Status Quo Perspective," MIS Quarterly, 33(3), pp.567-582.

Kim, S., and Lee, H. (2006). "The Impact of Organizational Context and Information Technology on Employee Knowledge-Sharing Capabilities," Public Administration Review, 66(3), pp.370-385.

King, W. R., and Marks, P. V. (2008). "Motivating Knowledge Sharing through a Knowledge Management System," Omega, 36(1), pp.131-146.

Kohli, R., and Devaraj, S. (2003). "Measuring Information Technology Payoff: A Meta-Analysis of Structural Variables in Firm-Level Empirical Research," Information Systems Research, 14(2), pp.127-145.

Kulkarni, U. R., Ravindran, S., and Freeze, R. (2006). "A Knowledge Management Success Model: Theoretical Development and Empirical Validation," Journal of Management Information Systems, 23(3), Winter2006/2007, pp.309-347.

Laguna, K., and Babcock, R. L. (1997). "Computer Anxiety in Young and Older Adults: Implications for HumanComputer Interactions in Older Populations," Computers in Human Behavior, 13(3), pp.317-326.

Larson, A. (1992). "Network Dyads in Entrepreneurial Settings: A Study of the Governance of Exchange Relation- ships," Administrative Science Quarterly, 37(1), pp.76-104.

Lebie, L., Rhoades, J. A., and McGrath, J. E. (1996). "Interaction Process in Computer-Mediated and Face-to-Face Groups," Computer Supported Cooperative Work, 4(2-3), pp.127-152.

Lee, G. K., and Cole, R. E. (2003). "From a Firm-Based to a Community-Based Model of Knowledge Creation: The Case of the Linux Kernel Development," Organization Science, 14(6), pp.633-649.

Lee, J.-H., and Kim, Y.-G. (2001). "Effects of Managerial Drivers and Climate Maturity on Knowledge Management Performance: Empirical Validation," Proceedings of the 5th Asia Pacific Conference on Information Systems (PACIS 2001), Paper 77, Seoul, Korea.

Lin, C.-P. (2007a). "To Share or Not to Share: Modeling Tacit Knowledge Sharing, Its Mediators and Antecedents," Journal of Business Ethics, 70(4), pp.411-428.

Lin, H.-F. (2007b). "Effects of Extrinsic and Intrinsic Motivation on Employee Knowledge Sharing Intentions," Journal of Information Science, 33(2), pp.135-149.

Lu, L., Leung, K., and Koch, P. T. (2006). "Managerial Knowledge Sharing: The Role of Individual, Interpersonal, and Organizational Factors," Management \& Organization Review, 2(1), pp.15-41.

Ma, M., and Agarwal, R. (2007). "Through a Glass Darkly: Information Technology Design, Identity Verification, and Knowledge Contribution in Online Communities," Information Systems Research, 18(1), pp.42-67.

Mayer, R. C., Davis, J. H., and Schoorman, F. D. (1995). "An Integrative Model of Organizational Trust," Academy of Management Review, 20(3), pp.709734. 
McAllister, D. J. (1995). "Affect- and Cognition-Based Trust as Foundations for Interpersonal Cooperation in Organizations," Academy of Management Journal, 38(1), pp.24-59.

Meyer, J. P., and Allen, N. J. (1997). Commitment in the Workplace: Theory, Research, and Application. Sage Publications: Thousand Oaks, CA.

Meyer, J. P., Allen, N. J., and Smith, C. A. (1993). "Commitment to Organizations and Occupations: Extension and Test of a Three-Component Conceptualization," Journal of Applied Psychology, 78(4), pp.538-551.

Molm, L. D. (2001). "Theories of Social Exchange and Exchange Networks," in: The Handbook of Social Theory, Edited by George Ritzer and Barry Smart. Sage Press: London, pp.260-272.

Mowday, R. T., Porter, L. W., and Steers, R. M. (1982). Employee-Organization Linkages: The Psychology of Commitment, Absenteeism, and Turnover. Academic Press: San Diego, CA.

Nahapiet, J., and Ghoshal, S. (1998). "Social Capital, Intellectual Capital, and the Organizational Advantage," Academy of Management Review, 23(2), pp.242-266.

Ng, T. W. H., and Butts, M. M. (2009). "Effectiveness of Organizational Efforts to Lower Turnover Intentions: The Moderating Role of Employee Locus of Control," Human Resource Management, 48(2), pp.289-310.

Nonaka, I. (1994). "A Dynamic Theory of Organizational Knowledge Creation," Organization Science, 5(1), pp.14-37.

O'Dell, C., and Grayson, C. J. (1998). If Only We Knew What We Know. The Free Press: New York.

O'Reilly, C., and Chatman, J. (1986). "Organizational Commitment and Psychological Attachment: The Effects of Compliance, Identification, and Internaliza- tion on Prosocial Behavior," Journal of Applied Psychology, 71(3), pp.492499.

Osterloh, M., and Frey, B. S. (2000). "Motivation, Knowledge Transfer, and Organizational Forms," Organization Science, 11(5), pp.538-550.

Pai, J.-C. (2006). "An Empirical Study of the Relationship between Knowledge Sharing and Is/It Strategic Planning (Issp)," Management Decision, 44(1), pp.105-122.

Pham, N. T., and Swierczek, F. W. (2006). "Facilitators of Organizational Learning in Design," Learning Organization, 13(2), pp.186-201.

Postmes, T., and Spears, R. (2000). "Redefining the Cognitive Definition of the Group: Deindividuation Effects in Common Bond Vs. Common Identity Groups," in: Side Issues Center Stage: Recent Developments in Studies of De-Individuation in Groups, T. Postmes, R. Spears, M. Lea and S. Reicher (eds.). Royal Netherlands Academy of Arts and Sciences: Amsterdam.

Postmes, T., Tanis, M., and DeWit, B. (2001). "Communication and Commitment in Organizations: A Social Identity Approach," Group Processes and Intergroup Relations, 4(3), pp.227-246.

Renzl, B. (2008). "Trust in Management and Knowledge Sharing: The Mediating Effects of Fear and Knowledge Documentation," Omega, 36(2), pp.206220.

Robert Jr., L. P., Dennis, A. R., and Hung, Y.T. C. (2009). "Individual Swift Trust and Knowledge-Based Trust in Faceto-Face and Virtual Team Members," Journal of Management Information Systems, 26(2), pp.241-279.

Rosenthal, R. (1991). Meta Analytic Procedures for Social Research. Sage Publications: Newbury Park, CA. 
Knowledge Sharing as Social Exchange: Evidence from a Meta-Analysis / Liu et al.

Ruggles, R. (1998). "The State of the Notion: Knowledge Management in Practice," California Management Review, 40(3), Spring98, pp.80-89.

Ryan, R. M., and Deci, E. L. (2000). "Intrinsic and Extrinsic Motivations: Classic Definitions and New Directions," Contemporary Educational Psychology, 25(1), pp.54-67.

Sabherwal, R., Jeyaraj, A., and Chowa, C. (2006). "Information System Success: Individual and Organizational Determinants," Management Science, 52(12), pp.1849-1864.

Sambamurthy, V., and Subramani, M. (2005). "Special Issue on Information Technologies and Knowledge Mangement," MIS Quartely, 29(1), pp.1-7.

Scarbrough, H., and Swan, J. (2001). "Knowledge Communities and Innovation," in: Trends in Communication; Special Issue on Communities of Practice, M. Huysman and P. Van Baalen (eds.). Boom: Amsterdam, pp.7-20.

Sharma, R., and Yetton, P. (2003). "The Contingent Effects of Management Support and Task Interdependence on Successful Information Systems Implementation," MIS Quarterly, 27(4), pp.533-555.

Sharma, R., and Yetton, P. (2007). "The Contingent Effects of Training, Technical Complexity, and Task Interdependence on Successful Information Systems Implementation," MIS Quarterly, 31(2), pp.219-238.

Shih, Y.-Y., and Huang, S. S. (2009). "The Actual Usage of Erp Systems: An Extended Technology Acceptance Perspective," Journal of Research and Practice in Information, 41(3), pp.263276.

Thibaut, J. W., and Kelley, H. H. (1959). The Social Psychology of Groups. Wiley: New York.
Tsai, W., and Ghoshal, S. (1998). "Social Capital and Value Creation: The Role of Intrafirm Networks," Academy of Management Journal, 41(4), pp.464476.

Van den Hooff, B., and de Ridder, J. A. (2004). "Knowledge Sharing in Context: The Influence of Organizational Commitment, Communication Climate and $\mathrm{Cmc}$ Use on Knowledge Sharing," Journal of Knowledge Management, 8(6), pp.117-130.

Van den Hooff, B., Elving, W., Meeuwsen, J. M., and Dumoulin, C. (2003). "Knowledge Sharing in Knowledge Communities," in: Communities and Technologies. Kluwer, B.V. pp.119141.

Van den Hooff, B., Leeuw, D., and van Weenen, F. S. (2004). "Committed to Share: Commitment and $\mathrm{Cmc}$ Use as Antecedents of Knowledge Sharing," Knowledge and Process Management, 11(1), pp.13-24.

Van Knippenberg, D., and Sleebos, E. (2006). "Organizational Identification Versus Organizational Commitment: SelfDefinition, Social Exchange, and Job Attitudes," Journal of Organizational Behavior, 27(5), pp.571-584.

Van Knippenberg, D., and Sleebos, E. (2006). "Organizational Identification Versus Organizational Commitment: SelfDefinition, Social Exchange, and Job Attitudes," Journal of Organizational Behavior, 27(5), pp.571-584.

Walther, J. B. (1996). "Computer-Mediated Communication: Impersonal, Interpersonal and Hyperpersonal Interaction," Communication Research, 23(1), pp.3-43.

Wang, C.-C. (2004). "The Influence of Ethical and Self-Interest Concerns on Knowledge Sharing Intentions among Managers: An Empirical Study," International Journal of Management, 21(3), pp.370-381. 
Warkentin, M. E., Sayeed, L., and Hightover, R. (1997). "Virtual Teams Verus Faceto-Face Teams: An Exploratory Study of a Web-Based Conference System," Decision Sciences, 28(4), pp.975-996.

Wasko, M. M., and Faraj, S. (2005). "Why Should I Share? Examining Social Capital and Knowledge Contribution in Electronic Networks of Practice," MIS Quarterly, 29(1), pp.35-57.

Watson, S., and Hewett, K. (2006). "A MultiTheoretical Model of Knowledge Transfer in Organizations: Determinants of Knowledge Contribution and Knowledge Reuse," Journal of Management Studies, 43(2), pp.141-173.

Weisband, S., P. (1992). "Group Discussion and First Advocacy Effects in Computer-Mediated and Face-to-Face Decision Making Groups," Organizational Behavior and Human Decision Processes, 53(3), pp.352-380.

Willem, A., and Buelens, M. (2007). "Knowledge Sharing in Public Sector Organizations: The Effect of Organizational Characteristics on Interdepartmental Knowledge Sharing," Journal of Public Administration Research \& Theory, 17(4), pp.581-606.

Ye, S., Chen, H., and Jin, X. (2006). "Exploring the Moderating Effects of Commitment and Perceived Value of Knowledge in Explaining Knowledge Contribution in Virtual Communities," in: Proceedings of the 10th Asia Pacific Conference on Information Systems (PACIS 2006), Paper 25. Kuala Lumpur, Malaysia.

Yeh, Y. J., Lai, S. Q., and Ho, C. T. (2006). "Knowledge Management Enablers: A Case Study," Industrial Management and Data Systems, 106(6), pp.793810.

Yuan, M., Vogel, D., Zhang, X., Chen, Z., and Chu, X. (2007). "Antecedents of Coordination Effectiveness of Software Developer Dyads from Interacting
Teams: An Empirical Investigation," Proceedings of the 11th Asia Pacific Conference on Information Systems (PACIS 2007), Paper 82, Auckland, New Zealand.

\section{Appendix A - Studies Included in the Meta-Analysis}

Bakker, M., Roger Th, A. J. L., Gabbay, S. M., Kratzer, J., and Van Engelen, J. M. L. (2006). "Is Trust Really Social Capital? Knowledge Sharing in Product Development Projects," Learning Organization, 13(6), pp.594-605.

Bartol, K. M., Liu, W., Zeng, X., and Wu, K. (2009). "Social Exchange and Knowledge Sharing among Knowledge Workers: The Moderating Role of Perceived Job Security," Management and Organization Review, 5(2), pp.223-240.

Burgess, D. (2005). "What Motivates Employees to Transfer Knowledge Outside Their Work Unit?," Journal of Business Communication, 42(4), pp.324-348.

Cabrera, Á., Collins, W. C., and Salgado, J. F. (2006). "Determinants of Individual Engagement in Knowledge Sharing," International Journal of Human Resource Management, 17(2), pp.245264.

Cai, S., and Xu, Y. (2008). "Voluntary Knowledge Sharing in Organizations," Proceedings of the 12th Asia Pacific Conference on Information Systems (PACIS 2008), Paper 59, Suzhou, China.

Chai, S., Dasy, S., and Raoz, H. R. (2008). "An Exploratory Study of Bloggers' Information Sharing Behavior: The Role of Online Privacy Concerns," Proceedings of the 14th Americas Conference on Information Systems (AMCIS 2008), Paper 282, Toronto, Canada.

Chang, C.-M., Yen, C.-H., and Cheng, H.-L. (2009). "Trust-Building Mechanisms 
Knowledge Sharing as Social Exchange: Evidence from a Meta-Analysis / Liu et al.

and Knowledge Sharing in Virtual Communities," Proceedings of the 9th International Conference on Electronic Business (ICEB 2009), Macau.

Chang, K. T.-T. (2008). "Psychological Contracts and Knowledge Exchange in Virtual Teams," Proceedings of the 29th International Conference on Information Systems (ICIS 2008), Paper 146, Paris, France.

Chiu, C.-M., Hsu, M.-H., and Wang, E. T. G. (2006). "Understanding Knowledge Sharing in Virtual Communities: An Integration of Social Capital and Social Cognitive Theories," Decision Support Systems, 42(3), pp.1872-1888.

Ferrin, D. L., and Dirks, K. T. (2003). "The Use of Rewards to Increase and Decrease Trust: Mediating Processes and Differential Effects," Organization Science, 14(1), pp.18-31.

Foss, N. J., Minbaeva, D. B., Pedersen, T., and Reinholt, M. (2009). "Encouraging Knowledge Sharing among Employees: How Job Design Matters," Human Resource Management, 48(6), pp.871-893.

Gupta, K. S. (2008). "A Comparative Analysis of Knowledge Sharing Climate," Knowledge \& Process Management, 15(3), pp.186-195.

Hernandez, J. M., and dos Santos, C. C. (2010). "Development-Based Trust: Proposing and Validating a New Trust Measurement Model for Buyer-Seller Relationships," Brazilian Administration Review, 7(2), pp.172-197.

Ho, Z. W., and Chang, K. (2009a). "Justice Perceptions, Individual Centrality and Knowledge Contribution Distinctions in Global Organization," Proceedings of the 13th Pacific-Asia Conference on Information Systems (PACIS 2009), Hyderabad, India, 10 to 12 July 2009.

Ho, Z. W., Chang, K. T.-T., and Kankanhalli, A. (2010). "The Impact of Individual Centrality and Helping on Knowledge
Sharing: A Study of Fit," Proceedings of the 16th Americas Conference on Information Systems (AMCIS 2010), Lima.

Ho, Z. W., and Chang, T. T. K. (2009b). "The Dissimilar Effects of Fairness on Knowledge Sharing in Distributed Workgroups: A Social Network Perspective," Proceedings of the 30th International Conference on Information Systems (ICIS 2009), Paper 119, Phoenix, Arizona, USA.

Hsu, M.-H., Ju, T. L., Yen, C.-H., and Chang, C.-M. (2007). "Knowledge Sharing Behavior in Virtual Communities: The Relationship between Trust, SelfEfficacy, and Outcome Expectations," International Journal of HumanComputer Studies, 65(2), pp.153-169.

Ibragimova, B., and Ryan, S. D. (2008). "Enabling Attributes for Team-Based Knowledge Sharing: A Preliminary Empirical Test," Proceedings of the 14th Americas Conference on Information Systems AMCIS 2008), Toronto, Canada, 14-17 August 2008.

Jacobs, E., and Roodt, G. (2007). "The Development of a Knowledge Sharing Construct to Predict Turnover Intentions," Aslib Proceedings, pp.229-248.

Kim, S., and Lee, H. (2006). "The Impact of Organizational Context and Information Technology on Employee Knowledge-Sharing Capabilities," Public Administration Review, 66(3), pp.370-385.

King, W. R., and Marks, P. V. (2008). "Motivating Knowledge Sharing through a Knowledge Management System," Omega, 36(1), pp.131-146.

Kroumova, M., and Lazarova, M. (2009). "Broad-Based Incentive Plans, $\mathrm{Hr}$ Practices and Company Performance," Human Resource Management Journal, 19(4), pp.355-374.

Lee, J.-H., and Kim, Y.-G. (2001). "Effects of Managerial Drivers and Climate Ma- 
turity on Knowledge Management Performance: Empirical Validation," Proceedings of the 5th Asia Pacific Conference on Information Systems (PACIS 2001), Paper 77, Seoul, Korea.

Liao, L.-F. (2006). "A Learning Organization Perspective on Knowledge-Sharing Behavior and Firm Innovation," $\mathrm{Hu}$ man Systems Management, 25(4), pp.227-236.

Liao, L.-F. (2008). "Knowledge-Sharing in R\&D Departments: A Social Power and Social Exchange Theory Perspective," International Journal of Human Resource Management, 19(10), pp.1881-1895.

Lin, C.-P. (2007a). "To Share or Not to Share: Modeling Tacit Knowledge Sharing, Its Mediators and Antecedents," Journal of Business Ethics, 70(4), pp.411-428.

Lu, L., Leung, K., and Koch, P. T. (2006). "Managerial Knowledge Sharing: The Role of Individual, Interpersonal, and Organizational Factors," Management \& Organization Review, 2(1), pp.15-41.

Ma, M., and Agarwal, R. (2007). "Through a Glass Darkly: Information Technology Design, Identity Verification, and Knowledge Contribution in Online Communities," Information Systems Research, 18(1), pp.42-67.

Marett, K., and Joshi, K. D. (2009). "The Decision to Share Information and Rumors : Examining the Role of Motivation in an Online Discussion Forum," Communications of the AIS, 24(4), pp.47-68.

Ng, T. W. H., and Butts, M. M. (2009). "Effectiveness of Organizational Efforts to Lower Turnover Intentions: The Moderating Role of Employee Locus of Control," Human Resource Management, 48(2), pp.289-310.

Noor, N. L. M., Hashim, M., Haron, H., and Aiffin, S. (2005). "Community Acceptance of Knowledge Sharing Sys- tem in the Travel and Tourism Websites: An Application of an an Extension of Tam," Proceedings of the 13th European Conference on Information Systems (ECIS 2005), Paper 71, Regensburg, Germany.

Pham, N. T., and Swierczek, F. W. (2006). "Facilitators of Organizational Learning in Design," Learning Organization, 13(2), pp.186-201.

Phang, C. W., Kankanhalli, A., and Sabherwal, R. (2009). "Usability and Sociability in Online Communities: A Comparative Study of Knowledge Seeking and Contribution," Journal of the Association for Information Systems, 10(10), pp.721-747.

Quigley, N. R., Tesluk, P. E., Locke, E. A., and Bartol, K. M. (2007). "A Multilevel Investigation of the Motivational Mechanisms Underlying Knowledge Sharing and Performance," Organization Science, 18(1), pp.71-88.

Renzl, B. (2008). "Trust in Management and Knowledge Sharing: The Mediating Effects of Fear and Knowledge Documentation," Omega, 36(2), pp.206220.

Reychav, I., and Weisberg, J. (2009). "Good for Workers, Good for Companies: How Knowledge Sharing Benefits Individual Employees," Knowledge and Process Management, 16(4), pp.186197.

Shen, A. X. L., Lee, M. K. O., Cheung, C. M. K., and Chen, H. (2009). "An Investigation into Contribution I-Intention and We-Intention in Open Web-Based Encyclopedia: Roles of Joint Commitment and Mutual Agreement," Proceedings of the 30th International Conference on Information Systems (ICIS 2009), Paper 7, Phoenix, Arizona, USA.

Staples, D. S., and Webster, J. (2008). "Exploring the Effects of Trust, Task Interdependence and Virtualness on 
Knowledge Sharing as Social Exchange: Evidence from a Meta-Analysis / Liu et al.

Knowledge Sharing in Teams," Information Systems Journal, 18(6), pp.617-640.

Taylor, E. Z., and Murthy, U. S. (2009). "Knowledge Sharing among Accounting Academics in an Electronic Network of Practice," Accounting Horizons, 23(2), pp.151-179.

Van den Hooff, B., and de Ridder, J. A. (2004). "Knowledge Sharing in Context: The Influence of Organizational Commitment, Communication Climate and $\mathrm{Cmc}$ Use on Knowledge Sharing," Journal of Knowledge Management, 8(6), pp.117-130.

Wang, C.-C., and Lai, C.-Y. (2006). "Knowledge Contribution in the Online Virtual Community: Capability and Motivation," Knowledge Science, Engineering and Management, 4092), pp.442-453.

Wasko, M. M., and Faraj, S. (2005). "Why Should I Share? Examining Social Capital and Knowledge Contribution in Electronic Networks of Practice," MIS Quarterly, 29(1), pp.35-57.

Watson, S., and Hewett, K. (2006). "A MultiTheoretical Model of Knowledge Transfer in Organizations: Determinants of Knowledge Contribution and Knowledge Reuse," Journal of Management Studies, 43(2), pp.141-173.

Willem, A., and Buelens, M. (2007). "Knowledge Sharing in Public Sector Organizations: The Effect of Organizational Characteristics on Interdepartmental Knowledge Sharing," Journal of Public Administration Research \& Theory, 17(4), pp.581-606.

Wu, S., Lin, C. S., and Lin, T. C. (2006). "Exploring Knowledge Sharing in Virtual
Teams: A Social Exchange Theory Perspective," Proceedings of the 39th Annual Hawaii International Conference (HICSS 2006), Kauai, Hawaii, USA.

Wu, W.-Y., and Sukoco, B. M. (2010). "Why Should I Share? Examining Consumers' Motives and Trust on Knowledge Sharing," Journal of Computer Information Systems, 50(4), pp.11-19.

Ye, H., Feng, Y., and Choi, C. F. (2010). "Sustainability and Growth of Online Knowledge Communities: Examining the Importance of Perceived Community Support and Perceived Leader Support," Proceedings of the 31th International Conference on Information Systems (ICIS 2010), St. Louis, USA.

Yu, A. Y., Hao, J.-X., Dong, X.-Y., and Khalifa, M. (2010). "Revisiting the Effect of Social Capital on Knowledge Sharing in Work Teams: A Multilevel Approach," Proceedings of the 31 th International Conference on Information Systems (ICIS 2010), St. Louis, USA.

Yuan, M., Vogel, D., Zhang, X., Chen, Z., and Chu, X. (2007). "Antecedents of Coordination Effectiveness of Software Developer Dyads from Interacting Teams: An Empirical Investigation," Proceedings of the 11th Asia Pacific Conference on Information Systems (PACIS 2007), Paper 82, Auckland, New Zealand.

Zheng, J., and Kim, H.-W. (2007). "Investigating Knowledge Contribution from the Online Identity Perspective," Proceedings of the 28th International Conference on Information Systems (ICIS 2007), Paper 143, Montreal, Quebec, Canada 


\section{About Authors}

Dr. Chih-Chung Liu is an Assistant Professor in Department of Information Management at the National University of Chia Nan University of Pharmacy and Science (CHNA), Tainan, Taiwan. He has more than 13 years of experience in the IT industry on many information systems development prior to joining CHNA. He received Ph.D. from National Sun Yat-Sen University of Taiwan in 2010. His current research interests are in the areas of knowledge management, project management, and online communities. His work has been published in Industrial Management and Data Systems, ICIS and PACIS.

Dr. Ting-Peng Liang is National Chair Professor of Information Systems at National Cheng-Chi University (on leave from National Sun Yat-Sen University) in Taiwan. He received his Ph.D. from The Wharton School of the University of Pennsylvania. He has taught at the University of Illinois, Purdue University, Chinese University of Hong Kong, and City University of Hong Kong. His primary research interests include electronic commerce, knowledge management, intelligent systems, decision support systems, and strategic applications of information technologies. He has published many papers in refereed journals, including Management Science, MIS QuarterIy, JMIS, Operations Research, DSS, and IJEC, among others. He is the founding editor of the PAJAIS and has served on the editorial board for a dozen academic journals, including IJEC, DSS, and Journal of AIS.

Dr. Balaji Rajagopalan is Professor of Management Information Systems at Oakland University, Rochester, Michigan, USA and Pro Vice Chancellor \& Dean of the School of Business at Galgotias University, India. His research has been published or accepted in Information Systems Research, IEEE Transactions on Systems Man and Cybernetics, Journal of Database Management, European Journal of Operational Research, Communications of the ACM, Decision Support Systems and Journal of Medical Systems. Along with two co-principal investigators he was recently awarded a three year National Science
Foundation grant for $\$ 500,000$. Dr. Rajagopalan received his $\mathrm{MS}$ and $\mathrm{PhD}$ degrees from the University of Memphis, Tennessee in the USA in 1992 and 1999 respectively in Management Information Systems. He received his Bachelor of Engineering degree in Mechanical Engineering in 1988 from Andhra University. He served as Associate Dean in the School of Business at Oakland University from February 2010 for over two years. He was honored as the Stinson Leadership Fellow in 2010. Prior to his appointment as Associate Dean, he served in the roles of Director of Graduate Business Programs and Director of Executive MBA program at Oakland University. Dr. Rajagopalan also held faculty appointments at Illinois State University and Southern Arkansas University.

Dr. Vallabh. Sambamurthy (Ph.D., University of Minnesota, 1989) is the Eli Broad Professor of Information Technology at the Eli Broad College of Business at Michigan State University. His research examines how firms successfully leverage information technologies in their business strategies, products, services, and organizational processes. Most of his work has been funded by the Financial Executives Research Foundation, the Advanced Practices Council (APC), and the National Science Foundation. His work has been published in journals such as MIS Quarterly, Information Systems Research, Decision Sciences, Management Science, Organization Science, and IEEE Transactions on Engineering Management. He has served as a senior editor for MIS Quarterly, departmental editor for IEEE Transactions of Engineering Management, and Americas editor for Journal of Strategic Information Systems. Recently, he completed a six-year term as the editor-inchief of Information Systems Research. He was selected as a Fellow of the Association for Information Systems in 2009.

Jason Chia-Hsien $\mathbf{W u}$ is a doctoral candidate of Information Management at National Sun Yat-Sen University in Kaohuang, Taiwan. His primary research interests are in virtual community and service sciences. He has published a few papers in journals and conferences. 